\title{
The Form of the Body: John Pecham's Critique of Aquinas' Doctrine of the Soul and the Summa Halensis
}

\begin{abstract}
During the 1270s and 1280s, John Pecham developed an analysis on psychological issues, such as body/soul dualism, the unicity of powers of the soul, and the medium between body and soul. The master elaborated his own position by replying mainly to Thomas Aquinas' account concerning the body/soul relation. While Aquinas affirmed that the soul is the form of the body, suggesting that the two comprise one substance and the soul does not just make the body live but also makes it a body, Pecham thought that the soul is the perfection of the body, so that soul and body comprise two separate substances, and the soul does not make the body a body but only makes it live. The aim of this contribution is to show that in Pecham's polemical debating of the position of Aquinas, the three issues (i.e. body/soul dualism, unicity of powers, and medium between body and soul) are part of one and the same doctrinal perspective which the Franciscan master develops, making use of the tradition on 'psychology' to which also the Summa Halensis belongs.
\end{abstract}

The Franciscan John Pecham is seen as one of the major rivals of Thomas Aquinas in the 13th-century debate concerning the body/soul relation in the human being. The bone of contention between the two theologians was the notion of the soul as the form of the body, that is, the Aristotelian idea that the soul is the principle that organizes and moves the human body and thus forms one substance with it. In following Aristotle on this point, Aquinas aimed to avoid the risk of conceiving the intellect as separate from the body. In contrast to this thesis, Pecham appears concerned with defending the tradition which emphasizes the substantial difference between the soul and the body, which represent two different forms. This position, upheld in the Summa Halensis, represents for the Franciscan master the expression of a common doctrine held by Franciscan theologians, which he saw as the correct interpretation of the orthodox faith and tried to affirm even through the instrument of ecclesiastical censorship following his ascension to the post of archbishop of Canterbury.

The present essay intends to re-read Pecham's position, both in his writings as a master of theology and in the text of his censure of the doctrine of the unity of the substantial form, in the light of his relationship with the doctrinal tradition crystallized in the Summa. In doing this, the essay will first of all examine the different historiographical interpretations of the position of the Franciscan master, before moving on to examine the cornerstones of Aquinas' doctrine and the development of Pecham's response to it. In this way, the paper will underline the influence exerted 
by the tradition of the Summa Halensis on the construction of Pecham's position. It will also show how the relationship with this great Franciscan theological synthesis represents an element of continuity between Pecham's activity as a theologian and his ministry as 'Primate of All England'.

\section{Against the Unity of the Substantial Form: A Survey of the Historiography of the 1286 Condemnation}

The condemnation of eight doctrinal propositions that John Pecham, archbishop of Canterbury, issued on 30 April 1286 has been the subject of various historical evaluations by scholars of medieval philosophy and theology. ${ }^{1}$ In the decades between the two World Wars, which witnessed the development of a new stage of Neo-Thomism, Pecham's act began to be qualified as plainly belonging to the Anti-Thomism that emerged in the decades after Aquinas' death and which undermined the doctrinal value of the Dominican master's achievements. Palémon Glorieux describes the reaction of the Franciscan primate of the English Church to Aquinas' doctrine of the unity of the substantial form as part of the radical contest between the two mendicant orders which resulted in a net distinction between Thomists and Anti-Thomists or, more properly speaking, between Thomism and the peculiar form of Augustinianism that was developed by the Franciscan school, initially at least, mostly on the basis of pseudo-Augustinian writings interpreted through the lens of the highly original Islamic reader of Aristotle named Avicenna. ${ }^{2}$

With respect to this 'anti-Thomistic' understanding of Pecham's position, recent research on the 13th-century censures and condemnations of doctrines that were taught in the university has provided a different point of view. For instance, the studies of Luca Bianchi suggest interpreting the theological and philosophical debates among the masters in the context of a larger struggle for political and religious control over the university, and more specifically, over education and learning. Such a

1 The edition of the text of the condemnation is published in Registrum epitolarum fratris Ioannis Peckham, 3 vols, ed. T. Martin (London: Longman, 1882-85), vol. 3, pp. 921-23. A slightly different version of the text is recorded in the annals of the priory of Dunstable, edited in Annales Prioratus de Dunstaplia, ed. G. Laurd, in Annales monastici, vol. 3 (London: Longman, 1866), pp. 323-26. 2 P. Glorieux, Les premières polémiques thomistes I: Le correctorium corruptorii "Quare" (Paris: Vrin, 1927), p. viii. Glorieux edited the largest part of the literature of the correctoria corruptorii. See P. Glorieux, Les premières polémiques thomistes II: Le Correctorium Corruptorii "Sciendum" (Paris: Vrin, 1956). See also, of the same scholar, 'Les Correctoires: Essai de mise au point,' Recherches de théologie ancienne et médiévale 14 (1947), pp. 287-304; 'Pro et contra Thomam: Un survol de cinquante années,' in Sapientiae procerum amore: Mélanges médiévistes offerts à dom J.P. Müller, à l'occasion de son $70^{e}$ anniversaire, ed. T.W. Köhler (Rome: Editore Anselmiana, 1974), pp. 255-87. On the Neo-Thomist approach see also P. Mandonnet, 'Premiers travaux de plémique thomiste,' Revue des Sciences philosophiques et théologiques 7 (1913), pp. 46-70, 245-61. 
historical reading situates the 1286 condemnation in relation to the ecclesiastical authority to survey and control the orthodox faith with respect to the teaching provided in the studia of the religious orders or in the universities themselves. ${ }^{3}$

A quite different understanding of Pecham's initiative can be found in Alain Boureau's work, which presents the archbishop's doctrinal concern as plainly coherent with his own theological outlook. ${ }^{4}$ In particular, Boureau suggests that Pecham's engagement firstly in the debates and later in the condemnations was part of a larger opposition to Aquinas' doctrinal heritage and more specifically to the theological heirs of the Dominican master, such as Richard Knapwell, who defended the doctrine of the unity of the substantial form, despite its puzzling implications with respect to the status of Christ's dead body after his crucifixion and that of the Eucharistic sacrament. ${ }^{5}$ Moreover, the French historian stresses the strong biographical continuity between the teaching of the Franciscan master in Paris, Oxford, and the Papal curia, describing the 1286 condemnation issued during his time as archbishop of Canterbury as the logical result of a strong doctrinal conviction that he developed over his long career. Caleb Colley's recent focus on the contents of Pecham's writings on the unity or plurality of substantial forms stresses the crucial relevance of the Franciscan's intellectual biography to his thinking, highlighting his deepening engagement in the major debates in the university from 1270 concerning the status of the mendicants within the guild of masters, the eternity of the world, the unicity of the intellect, and the meaning of poverty. ${ }^{6}$

All these interpretations of Pecham's censure of 1286 assume a basic agreement between the masters and the ecclesiastical authorities who determined the orthodox faith and forbade the teaching of doctrines such as that regarding the unity of substantial form, which was seen by many as heterodox or heretical. It is certainly clear that the great censures of the 13th century concerning certain university teachings result from a complex connection between doctrinal discussions among the masters and the intervention of ecclesiastical authorities. The acts of $1241,{ }^{7} 1270,{ }^{8}$ and the no-

3 L. Bianchi, Censures et liberté intellectuelle à l'Université de Paris (Paris: Les Belles Lettres, 1999). 4 A. Boureau, Théologie, science et censure aux XIII siècle: Le cas de Jean Peckham (Paris: Les Belles Lettres, 2008).

5 Boureau, Théologie, science et censure aux XIII siècle, pp. 7-38.

6 C.G. Colley, 'The Plurality of Substantial Forms in John Peckham,' Franciscan Studies 73 (2015), pp. $59-80$.

7 See W.J. Courtenay, 'Dominicans and Suspect Opinion in the Thirteenth Century: The Case of Stephen of Venizy, Peter of Tarentasia, and the Articles of 1270 and 1271,' Vivarium 32 (1994), pp. 186-95; H.F. Dondaine, 'Hugues de S. Cher et la condamnation du 1241,' Revue des Sciences philosophiques et théologiques 33 (1949), pp. 170 - 74; Dondaine, 'Guerric de Saint-Quentin et la condamnation de 1241,' Revue des Sciences philosophiques et théologiques 44 (1960), pp. 225-42; L. Bianchi, 'Gli articoli censurati nel 1241/1244 e la loro influenza da Bonaventura a Gerson,' in Autour de Guilaume d'Auvergne († 1249): Etudes réunies, ed. F. Morenzoni, and J.-Y. Tilliette (Turnhout: Brepols, 2005), pp. 155-73; D. Grice, Church, Society and University: The Paris Condemnation of 1241/4 (London; New York: Routledge, 2020). 
torious condemnations of 1277 issued by Etienne Tempier in Paris and Robert Kilwardby in Oxford, depend on both the exercise of the ecclesiastical magisterium of a bishop and the theological support of the masters. ${ }^{9}$ However, scholars have clarified how the censure of certain statements or doctrines within the 13th-century university entailed a legal act which involved a process similar to a synod and produced a document which had certain specific literary features. This state of things places the censures and condemnations, including that of 1286 concerning the unity of the substantial form, at the crossroads between two different kinds of magisterium: that of the masters, who debated the solidity of certain doctrines amongst themselves, and that of the bishops, whose jurisdiction extended to the advocacy of what they considered the orthodox faith. ${ }^{10}$

In the light of these remarks, it will be useful to reconsider the supposed continuity between Pecham's teaching as a master and his governance of the English church which includes the 1286 condemnation. Certainly, the archbishop of Canterbury did not abandon his doctrinal convictions, but his exercise of the bishop's authority was driven by needs and concerns different from those of a magister. This historiographic assumption can help in dealing more closely with Pecham's position on the issue of substantial form. What emerges from his theological writings, especially the Tractatus de anima, the Quaestiones quodlibetales and the Quaestiones de anima, must be situated within the framework of the doctrinal confrontation of the 1270s on this issue, which was instigated by Thomas Aquinas' careful presentation of the unity of the substantial form in the first part of the Summa Theologiae. ${ }^{11}$ Pecham's

8 See J.M.M.H. Thijssen, Censure and Heresy at the University of Paris: 1200-1400 (Philadelphia: University of Pennsylvania Press, 1998).

9 See R. Hissette, Enquête sur les 219 articles condamnès à Paris le 7 mars 1277 (Louvain: Publications Universitaires, 1977); Aegidius Romanus, Apologia, ed. R. Wielockx (Florence: L. Olschki, 1985); R. Wielockx, 'Autour du procès de Thomas d'Aquin,' in Thomas von Aquin: Werk und Wirkung im Licht neuerer Forschungen, ed. A. Zimmermann (Berlin; New York: Walter De Gruyter, 1988), pp. 413-38; J.F. Wippel, 'Thomas Aquinas and the Condemnation of 1277,' The Modern Schoolman 72 (1995), pp. 233-72; R. Wielockx, 'Procédures contre Gilles de Rome et Thomas d'Aquin,' Revue des Scicences philosophiques et théologiques 83 (1999), pp. 293-313; S. Piron, 'Pour une critique interne de la condamnation du 7 mars 1277,' Recherches de théologie et philosophie médiévales 78:2 (2011), pp. 383-415. On Kilwardby's condemnation see D.E. Sharp, 'The 1277 Condemnation of Kilwardby,' The New Scholasticism 8 (1934), pp. 306-18; A.E. Larsen, The School of Heretics: Academic Condemnation at the University of Oxford, 1277-1409 (Leiden: Brill, 2011), pp. 25-41.

10 See D. Piché, La condamnation parisienne de 1277 (Paris: Vrin, 1999). On the multiple meanings of the term magisterium see Y. Congar, "Bref historique des formes du "Magistére" et de ses relations avec les docteurs,' Revue des Sciences philosophiques et théologiques 60 (1976), pp. 99-112; Congar, 'Pour une histoire sémantique du terme Magisterium,' Revue des Sciences philosophiques et théologiques 60 (1976), pp. 85-99.

11 For the edition of these texts of Pecham see Iohannes Pecham, Tractatus de anima, ed. G. Melani (Quaracchi: Collegium S. Bonaventurae, 1948); Pecham, Quodlibeta quatuor, ed. G.J. Etzkorn, F. Delorme (Grottaferrata: Collegium S. Bonaventurae, 1989); Pecham, Quaestiones de anima, in Quaes- 
theological production reflects the felt need to address the Dominican's philosophical innovation on the understanding of the body/soul relation, inspired by Aristotle. ${ }^{12}$ In the process, however, the master recovered a well-established tradition rooted in the intellectual engagement of the early Franciscan masters and fixed in the Summa Halensis. ${ }^{13}$ A survey of Pecham's position which assumes this point of view will clarify the place of the Franciscan master in the 1270 s discussion concerning the nature and role of the soul in the human composite, and will help to rethink the way such an academic matter became an issue in establishing the orthodox faith.

\section{The Soul as 'Pure Form': Aquinas and the Unity of the Substantial Form}

The introduction of the major Aristotelian philosophical works in 13th-century Latin Europe offered the possibility to directly deal with a new understanding of nature. More specifically, the metaphysical principle of the inseparability of matter and form was seen as the key to offering an explanation of substances based not on the simple combination of the four elements but rather on a universal structure according to which a body, and mainly a living body, is the result of the action of a form that organizes and properly structures the relevant matter. When this principle is applied to the human composite, the soul is understood as the form that gives order and life to matter: this approach agrees with Aristotle's definition of the soul in the De anima, according to which: 'the soul is the form of a natural body' and it

tiones disputatae, ed. G.J. Etzkorn, H. Spettmann, L. Oliger (Grottaferrata: Collegium S. Bonaventurae, 2002).

12 See on this D. Hasse, Avicenna's De anima in the Latin West: The Formation of a Peripatetic Philosophy of the Soul 1160-1300 (London: The Warburg Institute, 2000). On the developments of psychology between 1220 and the 1270s see R.A. Gauthier, 'Le Traité De anima et de potenciis eius d'un maître ès arts (vers 1225),' Revue des Sciences philosophiques et théologiques 66 (1982), pp. 27-55; Gauthier, 'Notes sur les débuts (1225-1240) du premier 'averroïsme',' Revue des Sciences philosophiques et théologiques 66 (1982), pp. 321-75. Gauthier, 'Notes sur Siger de Brabant I: Siger en 1265,' Revue des Sciences philosophiques et théologiques 67 (1983), pp. 201-33; Gauthier, 'Notes sur Siger de Brabant II: Aubry de Reims et la scission des Normands,' Revue des Sciences philosophiques et théologiques 68 (1984), pp. 3-39; Lectura in Librum De Anima a quodam discipulo reportata, ed. R.A. Gauthier (Grottaferrata: Collegium S. Bonaventurae, 1985). For a complete survey on the first half of the 13th century see M. Bieniak, The Soul-Body Problem at Paris, ca 1200-1250: Hugh of StCher and His Contemporaries (Leuven: Peeters, 2010).

13 See Lydia Schumacher, Early Franciscan Theology: Between Authority and Innovation (Cambridge: Cambridge University Press, 2019). For the edition of the Summa see Alexander of Hales, Doctoris Irrefragabilis Alexandri de Hales Ordinis minorum Summa theologica (SH), 4 vols (Quaracchi: Collegium S. Bonaventurae, 1924-48). 
is also 'the act of the body,' so that 'the soul is the prime act of a natural body which has life in potency. ${ }^{14}$

In question 75 of the Prima Pars of the Summa Theologiae Aquinas incorporates these elements within an account of the relation of the human soul to the body. Here, he starts by explaining that the soul is the first principle of life in the sense that it is not a body but the act which enlivens the body and makes it what it is. ${ }^{15}$ In elaborating a corollary of this view, Aquinas stresses that since the soul is the form of a body, it is impossible to attribute to the soul any kind of matter or material elements, because matter is pure potentiality, while the soul is the act of a body. In affirming this, he roundly rejects the universal hylomorphism that Franciscans adopted from Avicebron, according to which all substances, including the body and the soul, are individually comprised of their own kind of form and matter, even if it is only a spiritual matter in the case of the soul. Focusing on the human or rational soul, Aquinas notes that the form/matter relation remains unaltered:

It is clear that whatever is received into something is received according to the condition of the recipient. Now a thing is known in as far as its form is in the knower. But the intellectual soul knows a thing in its nature absolutely: for instance, it knows a stone absolutely as a stone; and therefore, the form of a stone, as to its proper formal idea, is in the intellectual soul absolutely. Therefore, the intellectual soul itself is an absolute form, and not something composed of matter and form. For if the intellectual soul were composed of matter and form, the forms of things could be received into it as individuals, and so it would only know the individual. As in the case of the sensitive powers which receive forms in a corporeal organ, matter is the principle by which forms are individualized. It follows, therefore, that the intellectual soul, and every intellectual substance which has knowledge of forms absolutely, is exempt from the composition of matter and form. ${ }^{16}$

14 Aristotle, De anima II, 1, 412a 19-21.

15 See Aquinas, Summa Theologiae, Ia , q. 75, a. 1. See on this B.C. Bazán, 'La corporalité selon saint Thomas,' Revue Philosophique de Louvain 51 (1983), pp. 369-409.

16 Aquinas, Summa Theologiae, Ia , q. 75, a. 5., co.: 'Manifestum est enim quod omne quod recipitur in aliquo, recipitur in eo per modum recipientis. Sic autem cognoscitur unumquodque, sicut forma eius est in cognoscente anima autem intellectiva cognoscit rem aliquam in sua natura absolute, puta lapidem inquantum est lapis absolute. Est igitur forma lapidis absolute, secundum propriam rationem formalem, in anima intellectiva. Anima igitur intellectiva est forma absoluta, non autem aliquid compositum ex materia et forma. Si enim anima intellectiva esset composita ex materia et forma, formae rerum reciperentur in ea ut individuales, et sic non cognosceret nisi singulare, sicut accidit in potentiis sensitivis, quae recipiunt formas rerum in organo corporali, materia enim est principium individuationis formarum. Relinquitur ergo quod anima intellectiva, et omnis intellectualis substantia cognoscens formas absolute, caret compositione formae et materiae.' The English translation of Aquinas' Summa is taken from the New Advent translation, available online at https:// www.newadvent.org/summa/. 
Aquinas argues that in the case of human beings, the form of the body is the rational soul, because the human soul is rational. ${ }^{17}$ As the form of the body, the rational soul is the principle that gives life to the human body, qua human, that is proper to a being whose specific act is understanding. In doing so, the Dominican master stresses the close relation between human soul and the human body, and thus defines a perspective which is contrary to other solutions on the body/soul relation. That is to say, he clearly argues against the idea of a separation between the potential intellect and the body, which is the one that derives from Averroes, and the Avicennian solution that the soul is related with the body as the mover to the moved.

The Dominican master concludes:

\begin{abstract}
There remains, therefore, no other explanation than that given by Aristotle - namely, that this particular man understands, because of the intellectual principle in his form. Thus, from the very operation of the intellect, it is made clear that the intellectual principle is the form. Thus, from the very operation of the intellect, it is made clear that the intellectual principle is united to the body as its form. The same can be clearly shown from the nature of the human species. For the nature of each thing is shown by its operation. Now the proper operation of the human being as human being is to understand; because the human thereby surpasses all other animals. Thus, also Aristotle concludes (Ethics X, 7) that the ultimate happiness of the human being must consist in this operation as properly belonging to it. The human being must therefore derive its species from that which is the principle of this operation. But the species of anything is derived from its form. It follows therefore that the intellectual principle is the proper form of the human being. ${ }^{18}$
\end{abstract}

Aquinas here distinguishes between two essential components of the human being as a substance, that is, the soul and the body. He does this by qualifying the soul as the form of the body and arguing that in the case of the human being, it is precisely the human soul, that is, the rational soul, which is the form of the body, giving life to it and making possible to do what is proper to human beings: perform the functions that characterize human life. Certainly, this allows the Dominican to present an alternative to an idea that the body and soul are two different substances and makes the intellect a sort of separate substance which would be unique for

17 See R.A. Velde, Participation and Substantiality in Thomas Aquinas (Leiden; Boston: Brill, 1995); J.F. Wippel, 'Thomas Aquinas and the Unity of Substantial Form,' in Philosophy and Theology in the Long Middle Ages: A Tribute to Stephen F. Brown, ed. K. Emery Jr., R. Friedmann, and A. Speer (Leiden: Brill, 2011), pp. 117-54.

18 Aquinas, Summa Theologiae $\mathrm{I}^{\mathrm{a}}$, q. 76, a. 1, co.: 'Relinquitur ergo solus modus quem Aristoteles ponit, quod hic homo intelligit, quia principium intellectivum est forma ipsius. Sic ergo ex ipsa operatione intellectus apparet quod intellectivum principium unitur corpori ut forma. Potest etiam idem manifestari ex ratione speciei humanae. Natura enim uniuscuiusque rei ex eius operatione ostenditur. Propria autem operatio hominis, inquantum est homo, est intelligere, per hanc enim omnia animalia transcendit. Unde et Aristoteles, in libro Ethic., in hac operatione, sicut in propria hominis, ultimam felicitatem constituit. Oportet ergo quod homo secundum illud speciem sortiatur, quod est huius operationis principium. Sortitur autem unumquodque speciem per propriam formam. Relinquitur ergo quod intellectivum principium sit propria hominis forma.' 
all mankind. However, it marks a real novelty with respect to the way the notion of substantial form was commonly advocated in the 1230s and 1240s, during the early reception of the philosophical sources concerning the doctrine of the soul. Such an approach gave rise to a series of problems concerning the consequences that an understanding of the human soul as pure form has on the processes of generation of the human being and of its corruption and death. ${ }^{19}$ In specific, the idea that the body represents its own substance was perceived as needed to explain how a dead body is still that of the person who died.

Throughout the 1270s, university masters discussed these issues concerning the doctrine of the unity of the substantial form, thus considering how the human soul can be described as the form of the body, and developed different arguments in response to which John Pecham offered his own contribution. ${ }^{20}$ Between 1270 and his election to the see of Canterbury in 1279, the Franciscan master's scholarly career brought him to Paris, Oxford, and the studium linked to the papal curia. Pecham developed his own position in light of two points of reference: hylomorphism or matterform composition as the basic structure of all substances, and the substantial difference between the soul and body. In line with these two ideas, the master addressed three major issues: the plurality of forms, the relation between body and soul, and the role of the rationes seminales. In dealing with each of these three issues, Pecham constantly invoked these concepts, which he found in the Summa Halensis.

\section{Unity Versus Plurality}

In the Tractatus de anima as well as in the Quaestiones quodlibetales and the Quaestiones de anima, Pecham fully affirms the so-called doctrine of 'universal hylomorphism', or the idea of Avicebron that all substances including the soul itself are comprised of matter and form. This entails that both the body and the soul presuppose a plurality of forms, or one substantial form which has different degrees. ${ }^{21}$ To clarify his position, Pecham distinguishes between two kinds of form. On the one hand there is a forma prima substantialis, which is the cause of the unity of a being. On

19 For a critical analysis of the doctrinal consequences of Aquinas' doctrines see the works of B.C. Bazán, 'The Human Soul: Form and Substance? Thomas Aquinas' Critique of Eclectic Aristotelianism,' Archives d'histoire doctrinale et littéraiere du Moyen Âge 64 (1997), pp. 515-69; 'The Creation of the Soul According to Thomas Aquinas,' in Philosophy and Theology in the Long Middle Ages, pp. 515-69; 'Can It be Proved, Following Thomas's Philosophical Principles, That the Human Soul is Naturally Incorruptible?,' in Contemplation and Philosophy: Scholastic and Mystical Modes of Medieval Philosophical Thought: A Tribute to Kent Emery, Jr., ed. R. Hofmeister Pich and A. Speer (Leiden; Boston: Brill, 2018), pp. 232-75.

20 For an account of the biography of Pecham see D. Douie, Archbishop Pecham (Oxford: Clarendon Press, 1952).

21 See G.A. Wilson, ‘The Critique to Thomas Aquinas's Unicity Theory of Forms on John Peckham's Quodlibet IV (Romanum),' Franciscan Studies 56 (1998), pp. 423-31. 
the other hand, there are other forms, namely the formae naturales, which are the cause of physical mutability of a being but do not affect its unity as a substance. ${ }^{22}$ Thus, the unity of being, depending on the forma prima substantialis, can be combined with the presence of a plurality forms, and this allows Pecham to argue differently from Aquinas on the nature of the intellectual or rational soul in its relation with the body. According to the Franciscan master, the rational soul is not the only form of the human body, because the distinction between the rational soul and the body entails that the latter possesses its own form which is comprised through the mixture of the four elements according to the features proper to the human being. ${ }^{23}$ This approach allows Pecham to explain more easily how the rational soul of each human being is able to exist also outside the union with the body. For Pecham, the status of the rational soul as the form of the body makes it the giver of life to the body, but this does not imply that it needs to be united with the body to exist: on the contrary, as John notes, the body exists in its corporeality before the infusion of the human soul, which is the 'formal cause' in the sense of being the cause of life for the body. However, it is not the unique form which operates in a body and causes its existence.

Pecham notes:

Some of the forms are those that do not need to be kept in existence, as is the case with human souls, or those forms that are the principles of life as they also live separate from the body. Others, on the other hand, are those forms which, in the matter they vivify, receive the foundation of existence and complementarily give back life to those substances 'in which living and giving life and other things clearly coincide,' because they die together with the body and arise from the principles of the body. ${ }^{24}$

The idea that the rational soul's life does not depend on simply being the giver of life to the human being, or on being its unique substantial form, is a development of an argument that the master may have found in the Summa Halensis concerning the way a living being can give life to another being, and therefore serve in a certain sense as its formal cause. In addressing this question, the Summa explains, following Avicenna, that the reason for the conjunction of a soul with a body is the desire of the former to bring the latter to life and to perfect it, that is, to bring the latter into act. On this basis, the text notes that this conjunction has multiple forms and that in certain beings the capability to create the conjunction is stronger and more effective than in others.

22 Pecham, Quodlibet, ed. Etzkorn and Delorme, pp. 198-99.

23 Pecham, Quodlibet, ed. Etzkorn and Delorme, pp. 230-31.

24 Pecham, Tractatus de anima, ed. Melani, p. 7: 'Sed formarum quaedam sunt quae substantiae in esse non indigent alio, sicut animae humanae, vel ita sunt principia vitae ut etiam vivant a corpore separatae; aliae autem sunt quae, in materia quam vivificant, recipiunt fundamentum exsistendi et ipsis rependunt complementum vivendi, "in quibus pro certo idem est vivere et vitam tribuere alteri," quia simul cum corpore moriuntur et oriuntur a principiis corporis.' 
The Summa continues with words that Pecham echoed in the passage quoted above:

In some beings, living and giving life to others coincide. Therefore, as regards some souls and bodies there is a sort of single life or single fulfilment of life, as in the case of the vegetative and sensitive souls: these, in fact, do not have of themselves some distinctive traits as regards life other than what they draw from the body. Therefore, also for their own life, they depend on the body, and their life cannot be separated from this. In other entities, however, like the rational soul, living and giving life to the body do not coincide, although they derive from the same thing, that is, from the same appetite. Indeed, the rational soul has a life of its own which is not that of the body; rather it is from the soul that life is ascribed to the body and therefore the soul alone, by reason of the life that is proper to it, is separable from the body. ${ }^{25}$

The different kinds of conjunction between the soul and the body and the different kinds of relation between living and giving life that the Summa Halensis presents are the background against which Pecham develops his idea of the plurality of forms. The rational soul, to act as the form of the body, does not need to be inseparable from matter and to be pure form. In such a case, in fact, the life of the rational soul and the life of the body coincide, since the proper act of the human soul is not to understand but rather to give life to the human body, so that its life is in act only by giving life to the body and once this latter action ends, the life of the human soul lacks its final cause.

\section{The Soul and the Body: The praesuppositum and the rationes seminales}

The use of the Summa in Pecham's argument emerges also in discussing the meaning of the term substantia and the possibility of defining the powers of the soul through it. The master notes that, with respect to the human soul, the term anima designates the intellect, that is, the soul that gives life to human beings, and this soul is not a perfect unity but rather it is composed of three substances, which correspond to three dimensions of life. Such a discussion is present both in the Tractatus and in the Quaestiones de anima. In the latter text, reacting against the hypothesis that there are a plurality of souls in the human being, Pecham argues in favor of the idea ac-

25 SH II, In4, Tr3, Q1, Ti2, C2, Ar2 (n. 483), Solutio, p. 669: 'In quibusdam enim quodam modo idem est vivere et vitam alii tribuere. Unde quarumdam animarum et corporum est quasi vita una et unum vitae complementum, ut in vegetabili et sensibili: hae enim de se non habent aliquam differentiam vitae nisi quam contrahunt a corpore; unde et secundum vitam suam dependent a corpore, et ideo vita eorum non est separabilis. In aliis vero, ut in rationali, non est idem vivere et vitam corpori tribuere, quamvis ab eodem sit ut ab appetitu, modo quo tactum est. Haec enim habet vitam propriam quae non est corporis; ab ipsa tamen derivatur unde tribuitur vita corpori, et ideo haec sola secundum vitam suam a corpore est separabilis.' 
cording to which, if it is impossible that the human being has more than one single soul, there is evidence nonetheless of the presence of multiple substances or spiritual natures in it. Therefore, as the body is ordered to the soul, so one kind of life is ordered to the other: the vegetative, to the sensitive, and these two to the rational. In outlining a distinction between the notions of soul as the cause of life and therefore as the giver of form, and the soul as a substance, the theologian explains:

Intellect is only meant by the name of soul. Therefore, by reason of this consideration it can be said that in the human being there is only one soul that gives it life, which is made up of a triple substance and a triple kind of life, that is, the vegetative, the sensitive and the intellectual. The vegetative soul and the sensitive soul are distinctive of the species as regards matter, because just as the vegetative soul of the human being differs from that of brutes as regards its species, so it also happens for the sensitive; from the point of view of the form, the species is characterized instead by the intellectual soul, about which it can be said that it has sensation according to a certain similarity. ${ }^{26}$

Such a theory that considers the soul as a unit but makes use of the notion of substance to designate the capabilities and the kind of life which depends on each capability, could be found in the Summa Halensis, in a passage which grounds the doctrinal position on the nature of the embryo.

Here the text of the Summa states:

Some thinkers argue, relying on Aristotle's statement cited above, that the embryo lives before being organized and that it has a vegetative and sensitive soul before the infusion of the rational soul. And they claim that the human being has three souls or at least three substances, as if they were three lives, that is, the vegetative, the sensitive and the intellectual. In fact, they affirm that the human being has an incorporeal substance thanks to which it lives, grows and is nourished, and this derives from generation, which the soul has in common with plants. It also has an incorporeal substance thanks to which it feels, which depends on the heavens and stars, which is transferred to it without mediation from God through creation. Therefore, they claim that there are three souls in the human being. Others affirm that although there are three substances in the human being, nevertheless there are not three souls, because the term 'soul' refers to a perfection: therefore, the vegetative substance is not a soul except in plants, of which it is the perfection, while the sensitive one is not a soul except in animals; but in the human being these substances are material principles with respect to reason, and the rational substance is the fulfilment of them, and therefore this alone is the soul in the human being while the others exist as material dispositions with respect to it. ${ }^{27}$

26 Pecham, Quaestiones de anima, ed. Etzkorn, Spettmann, and Oliger, pp. 362, 26-363, 6: 'Nomen animae solum significat intellectum. Ergo, secundum hoc dici potest unam esse in homine animam plene eum vivificantem, compositam ex triplici substantia et vita, scilicet vegetativa, sensitiva et intellectiva. Et per vegetativam et sensitivam poni in specie materialiter, quia [sicut] vegetativa humana specie differt a brutali, sic et sensitiva; sed formaliter per anima intellectivam, que in se potest dici habere sensum per quandam similitudinem.'

27 SH II, In4, Tr3, Q1, Ti2, C5 (n. 489), Solutio, p. 682: 'Quidam enim dicunt quod embrio vivit ante organizationem et habet animam vegetativam et sensitivam ante infusionem animae rationalis, innitentes verbo Philosophi supra dicto; et isti ponunt hominem habere tres animas vel saltem tres sub- 
The Summa notes that, strictly speaking, it is contrary to Augustine's authority to affirm that the human being has a plurality of souls, but doing so does not deny the value of the idea of three distinct principles, that is, the vegetative, the sensitive, and the rational, in the human soul. On the contrary, this text from the Summa affirms this possibility by tracing a clear conceptual distinction between the notion of soul and that of a substance. The same passage, with the detailed description of this doctrinal position, is quoted by Bonaventure, for whom the crucial point is how one understands a 'substance' and what it means to say that the soul is a substance. In his Commentary on the Sentences, Bonaventure more radically condemns as heretical the doctrine of the three souls in the human being, and then judges as erroneous and contrary to Augustine the doctrine of the three substances, which he attributes to philosophy. With reference to Augustine, Bonaventure develops the argument of the Summa Halensis to support the 'theological solution' according to which the human soul is one substance with different capabilities or faculties. ${ }^{28}$ Therefore, the human soul is one individual substance that perfects the human being by giving it life, sensation and intelligence.

Pecham's position, which describes the human soul as one and as responsible for the three degrees of life, because it has the faculties corresponding to each of these degrees, clearly stands in the doctrinal tradition which starts with the Summa Halensis and continues with Bonaventure. More in detail, Pecham was quite aware of the need to reshape the basic lexicon concerning the soul and its features and therefore he decided to make use of the Latin term substantia to signify not a permanent being, but rather a property or capability of beings. On his account, when the sources call the vegetative, sensitive and intellectual souls 'substances', they do not signify three distinct beings, but three capabilities of the same subject, the human soul, which defines the species of the human being as regards its matter (vegetative and sensitive) and as regards its form (rational). In doing so, Pecham offers a new understanding of the Aristotelian definition of the soul as the form of the body: the fact that the human being has one individual soul does not mean that this coincides with the intellect and that

stantias animae. Notandum ergo quod quidam dixerunt tres substantias incorporeas in homine, sicut tres vitas, scilicet vegetativam, sensitivam et intellectivam. Dicunt enim quod homo habet substantiam incorpoream, qua vivit, crescit et nutritur, et hoc ex traduce in generaitone, in qua convenit cum plantis; habet substantiam incorpoream, qua sentit, ex caelo et stellis, secundum quam convenit cum brutis; habet et substantiam, qua vivit et intelligit, immediate a Deo per creationem; unde ponunt tres anima in homine. Alii dicunt quod, quamvis sint tres substantiae, non tamen tres animae in homine, quia anima nomen est perfectionis; ideo substantia vegetabilis non est anima nisi in plantis, quarum est perfectio; sensibilis vero nisi in brutis; in homine autem sunt quasi materiales ad rationalem et rationalis est completio, et ideo ipsa sola est anima in homine, aliis existentibus ut dispositionibus materialibus ad ipsam.'

28 On the role of Bonaventure in the 13th-century theological discussions of the nature of human being see E.-H. Wéber, L'homme en discussion à l'université de Paris en 1270 (Paris: Vrin, 1970); Wéber, Dialogue et dissensions entre saint Bonaventure et saint Thomas à Paris (Paris: Vrin, 1974); Wéber, La persone humaine au XIII ${ }^{e}$ siècle (Paris: Vrin, 1991). 
the soul is the only substantial form of the body. Rather, the three capabilities or 'substances' which are proper to this soul define the human being in terms of its matter as well as its form, that is, the very nature of the human being qua 'human', or rational being.

\section{Rationes seminales: The Existence of the Body}

Pecham here introduces a clear distinction: on the one hand, the life of the human being qua human, that is, as a rational being whose proper form is the one that allows it to think and understand, is that which is caused by the intellect. In this sense, the human soul is the form of the body not because it organizes the matter of the body according to a certain structure and proportion. In other words, the human soul is not the cause of corporeality. Rather the human soul perfects and completes the human body because it causes it to lead the life of a rational being. This distinction between the life of the human soul qua human and its role of giver of life to the body leads Pecham to note that the death of an individual body does not involve the corruption and annihilation of its form, namely, the human soul, because the 'form' of the human body does not concern the physical organization of this body but only its actual enlivenment.

Following again an argument already stated in the Summa Halensis, Pecham notes that the human soul is connected to the body as the principle of its organization, but only in terms the desire (appetitus) to perfect it. In the Quaestiones de anima the master notes:

The soul wishes to be united with the body so that it can perform in some sense difficult acts: either because of fragility, as in the state of innocence, or because of danger, as in the state of misery. Trained by its actions, the soul acquires a noble disposition so that what is the least in the order of nature can achieve by merit a condition superior to that of the angels. ${ }^{29}$

The corporeality of the human being, by contrast, depends on other causes, namely, on the action of other formal principles which are responsible for the organization of corporeal matter according to a certain order and structure. In introducing this point of view, Pecham makes use of the Augustinian notion of rationes seminales, which is found already in the Summa Halensis in the context of drawing a distinction between causal reasons and seminal reasons. While the first concern the form, that is, the rea-

29 Pecham, Quaestiones de anima, ed. Etzkorn, Spettmann, and Oliger, p. 451, 18-23: 'Anima est substantia incorporea intelligibilis illuminationum quae sunt a primo ultima relatione precepta. Et ideo appetit uniri corpori ut exerceatur in actibus quodammodo difficilibus: vel ratione fragilitatis ut in statu innocentiae, vel ratione calamitatis [ut] in statu miseriae. In his autem exercita proficit ad habitus nobiles acquirendos, ut quae ultima est ordine naturae, posset supremum pertingere per meritum angelorum.' 
son a thing is that thing, the latter concern matter and its organization into a specific type of corporeal being. ${ }^{30}$ The text of the Summa explicitly stresses that these seminal reasons are the equivalent of the 'virtue of the soul' which Aristotle mentions as the cause of the corporeal organization of plants and animals:

So, from these parts of the world, which according to Aristotle are full of the power of the soul and which according to Augustine are full of the seminal reasons with which the world is pregnant, the opportunity presents itself, so that when the power of the first heaven and the inferior heaven concur with the generative power in the plant and in the animal and the simple capacity possessed by the same elements, the body is organized and there is a production of the sensitive and vegetative souls. ${ }^{31}$

The doctrine of the seminal reasons thus grounds the distinction of corporeality from the effects of the action of the human soul as a form of the body: this role of the soul does not concern matter but rather the perfection of the action of the body. The structure and order of matter in the human body, and its ability to exercise the vegetative and sensitive functions, depend on the seminal reasons, while the life of such a body as a human body depends on the action of the intellect.

Pecham's doctrinal perspective is therefore deeply marked by the idea of the plurality of forms: in the human being the soul is the form of the human body, while the seminal reasons, which are inherent in matter, are its formal cause qua body. This point of view highlights the clear distinction between the soul and the body, but in offering it, Pecham aims to include the hylomorphic principle in this understanding of the nature of the human being.

\section{From the Doctrinal Debate to the Condemnation of 1286: A Change of Framework}

In view of Aquinas' doctrine of the unicity of the substantial form, John Pecham assumes a position deeply rooted in a tradition that goes back to the Summa Halensis, which offers a reading of the Aristotelian ideas on the soul/body problem heavily influenced by Avicenna and interpreted in the light of the pseudo-Augustinian doctrinal inheritance. The Franciscan master shares with other contemporaries a series of theological doubts about the consequences of Aquinas' position, mainly with respect

30 SH II, In2, Tr3, S2, Q3, Ti3, C5, Ar2 (n. 236), Solutio, p. 291. On Augustine's role in Pecham's discourse see A. Collebant, 'Jean Peckham O.F.M. et l'augustinisme. Aperçus historique (1263-1285),' Archivum Franciscanum Historicum 18 (1925), pp. 441-72.

31 SH II, In4, Tr3, Q1, Ti2, C1, Ar2 (n. 481), Solutio, p. 663: 'Ex iis ergo mundi partibus, quae sunt plenae virtute animae, secundum Philosophum, sive rationibus seminalibus, quibus mundus est gravidus, secundum Augustinum, opportunitate accepta, ut quando confluunt virtus primi orbis et orbium inferiorum et virtus generativa in planta et in animali et virtus simplex indita ipsis elementis, sit corporis organizatio et productio animae sensibilis in esse et animae vegetabilis.' 
to the resurrection of Christ and the Eucharist. What William de La Mare affirms in his notorious Correctorium in 1277 can be seen as the synthesis of a critical discussion of Aquinas' heritage, offered from the point of view of theology. ${ }^{32}$

This discussion began probably when Aquinas was still alive, in the early 1270s, among the masters of the Parisian university, but it did not change in light of the view of the critics of the doctrine of the unity of the substantial form nor of Aquinas himself. Therefore, the discussion started and developed within the university, as part of the complex cultural process of rethinking theology in light of philosophical innovations, especially in the fields of metaphysics and the philosophy of nature, which were enhanced through the study of Aristotle and his Greek and Arabic commentary tradition. The year 1277 is certainly a turning point, since the debates regarding certain doctrines of Aquinas was seen as a matter of not only theological consistency, but also of orthodoxy. Étienne Tempier's intervention and above all Robert Kilwardby's list of condemned statements are the witnesses to a qualitative leap in the discussion: the university masters, in fact, were called to give their doctrinal support to the ecclesiastical authority by advising it on which specific theories appeared contrary to the faith, including that of the unity of the substantial form. In other words, it was an act that had a legal and political value, which had a series of theological reasons in its background, and by defining the limits of orthodoxy, intended to underline the role of ecclesiastical authorities in overseeing the university and its libertas. ${ }^{33}$ From the point of view of a bishop, in fact, the magisterium of those who taught in Paris and Oxford needed to be consistent with the magisterium of the successors to the apostles.

32 See R. Hissette, 'Albert le Grand et Thomas d'Aquin dans la censure parisienne du 7 mars 1277,' in Studien zur mittelalterlichen Geistesgeschichte und ihren Quellen, ed. A. Zimmermann (Berlin; New York: De Gruyter, 1982), pp. 226-46; Hissette, 'Trois articles de la seconde rédaction du Correctorium de Guillaume de La Mare,' Recherches de théologie ancienne et médiévale 51 (1984), pp. 230 -41; Hissette, 'L'implication de Thomas d'Aquin dans les censures parisiennes de 1277,' Recherches de théologie et philosophie médiévales 64 (1997), pp. 3-31; Hissette, 'Thomas d’Aquin compromis avec Gilles de Rome en mars 1277?,' Revue d'histoire ecclésiastique 93 (1998), pp. 5-26; L. Hödl, 'Neue Nachrichten über die Parisier Verurteilungen des thomasischen Formlehre,' Scholastik 39 (1964), pp. 178-96; Hödl, 'Anima forma coporis: Philosophisch-theologische Erhebungen zur Grundformel der scholastischen Anthropologie im Korrektorienstreit (1277-1287),' Theologie und Philosophie 41 (1966), pp. 536 -56; M.J.F.M. Hoenen, 'Being and Thinking in the Correctorium fratris Thomae and the Correctorium corruptorii Quare: Schools of Thought and Philosophical Methodology,' in Nach der Verurteilung von 1277: Philosophie und Theologie and der Universität von Paris im letzten Viertel des 13. Jahrhunderts, ed. J.A. Aertsen, K. Emery Jr., and A. Speer (Berlin; New York: De Gruyter, 2001), pp. 417-35. 33 S.L. Uckelman, 'Logic and the Condemnation of 1277,' Journal of Philosophical Logic 39 (2010), pp. 201-27; L.E. Wilshire, 'Were the Oxford Condemnations of 1277 Directed Against Aquinas?,' New Scholasticism 48 (1964), pp. 125-32; O. Lewry, 'The Oxford Condemnation of 1277 in Grammar and Logic,' in English Logic and Semantic from the 12th Century to the Times of Ockham and Burley, ed. H.A.G. Braakhuis, L.M. De Rijk (Nijmegen: Ingenium Publishers, 1981), pp. 235-77. For a detailed survey on Kilwardby's intellectual life see, A Companion to the Philosophy of Robert Kilwardby, ed. H. Lagerlund and P. Thorn (Leiden; Boston: Brill, 2013). 
This evident shift from a strictly academic and cultural field to a juridical and ecclesiastical one is what emerges from Pecham's own biography, specifically from his involvement in the discussion of the unity or plurality of substantial forms. The 1286 act, in fact, represents the will to reaffirm the archbishop of Canterbury's magisterial authority and that of the English Church in overseeing teaching of the university masters. The condemnation issued in London was not so much against Thomas Aquinas, but against the violation of Kilwardby's censorship of 1277, and therefore counteracted the teaching of the doctrine of the unity of the substantial form that the Thomists present in Oxford, such as Richard Knapwell, continued to promulgate. ${ }^{34}$ Quite remarkable, on this point, is the opposition that emerges in the letters and documents of the archbishop between the image of a pious and humble Aquinas and that of the arrogant Oxford Thomists.

Therefore, Pecham's choice to detail the reasons for the condemnation also on theological grounds must be situated within this context, which involves ecclesiastical and religious motivations and shows the archbishop in his capacity as primate of the English church rather than as a theologian who supported the plurality of substantial forms against the unity professed by Aquinas.

Certainly, Pecham's theological context provides an essential basis for understanding the modalities and contents of the censure of 1286, which in fact echoes the theological discussions of fifteen years before, when in Paris, in the presence of Aquinas himself, the unity of the substantial form had been discussed and criticized by the masters of theology. It is in that context that the Franciscan master developed his mature position, learning from Aquinas the importance of doing so in relation to the texts of Aristotle and his interpreters. However, he also tried to remain faithful to a certain theological orientation, which he saw as codified in the Summa Halensis. This text, in fact, was for Pecham a sort of herald of the opinio communis of the Franciscan masters of theology.

34 See Larsen, The School of Heretics, pp. 42-63; F. Pelster, 'Die Sätze der Londoner Verurteilung von 1286 und die Schriften des Magisters Richard Knapwell O.P.,' Archivum Fratrum Praedicatorum 16 (1946), pp. 83-106; Richard Knapwell, Quaestio disputata de unitate formae, ed. F.E. Kelly (Paris: Vrin, 1982); D.A. Callus, The Condemnation of St Thomas at Oxford (Oxford: Blackfriars, 1946). An evaluation of Pecham's archbishopric in terms of 'reform', that is of restoration of the authority of the English church is available in M. Powicke, The Thirteenth Century, 1216-1307 (Oxford: Clarendon Press, 1962), pp. 445-509. For Pecham's attitude against Aristotelianism during his ruling of the English Church see, T. Crowley, 'John Peckham, O.F.M., Archbishop of Canterbury, versus the New Aristotelianism,' Bulletin of the John Rilands Library 33 (1951), pp. 242-55. 